Article

\title{
Sequential Bioleaching of Pyritic Tailings and Ferric Leaching of Nonferrous Slags as a Method for Metal Recovery from Mining and Metallurgical Wastes
}

\author{
Natalya Fomchenko (D) and Maxim Muravyov *(D) \\ Winogradsky Institute of Microbiology, Research Centre «Fundamentals of Biotechnology» of the Russian \\ Academy of Sciences, Leninsky Ave., 33, bld. 2, 119071 Moscow, Russia; natalya.fomchenko@gmail.com \\ * Correspondence: maxmuravyov@inmi.ru; Tel.: +7-495-135-0421
}

Received: 14 October 2020; Accepted: 5 December 2020; Published: 7 December 2020

\begin{abstract}
In this work, we proposed a method for biohydrometallurgical processing of mining (old pyritic flotation tailings) and metallurgical (slag) wastes to recover gold and other nonferrous metals. Since this processing allows the removal of toxic metals or at least decreases their content in the solids, this approach may reduce the negative environmental impacts of such waste. The proposed process was based on pyritic tailings' bioleaching to recover metals and produce leach liquor containing a strong oxidizing agent (ferric sulfate) to dissolve nonferrous metal from slag. This approach also allows us to increase concentrations of nonferrous metals in the pregnant leach solution after pyritic waste bioleaching to allow efficient extraction. The old pyritic tailings were previously leached with $0.25 \%$ sulfuric acid for $10 \mathrm{~min}$ to remove soluble metal sulfates. As a result, $36 \%$ of copper and $35 \%$ of zinc were extracted. After 12 days of bioleaching with a microbial consortium containing Leptospirillum spp., Sulfobacillus spp., Ferroplasma spp., and Acidithiobacillus spp. at $35{ }^{\circ} \mathrm{C}$, the total recovery of metals from pyritic tailings reached $68 \%$ for copper and $77 \%$ for zinc; and subsequent cyanidation allowed $92 \%$ recovery of gold. Ferric leaching of two types of slag at $70{ }^{\circ} \mathrm{C}$ with the leachate obtained during bioleaching of the tailings and containing $15 \mathrm{~g} / \mathrm{L}$ of $\mathrm{Fe}^{3+}$ allowed 88.9 and $43.4 \%$ recovery of copper and zinc, respectively, from copper slag within $150 \mathrm{~min}$. Meanwhile, $91.5 \%$ of copper, $84.1 \%$ of nickel, and $70.2 \%$ of cobalt were extracted from copper-nickel slag within 120 min under the same conditions.
\end{abstract}

Keywords: bioleaching; ferric leaching; slags; flotation tailings; waste utilization

\section{Introduction}

The main source of copper and zinc is concentrated sulfidic ores. Sulfide concentrates of nonferrous metals are processed in mining plants, while the wastes from ore concentration (primarily froth flotation tailings) are stockpiled in tailing dumps [1]. The production of metals in pyrometallurgical plants is also associated with slag waste formation [2].

Billions of tons of flotation tailings have been accumulated in Russia (and globally), mainly due to ore-processing plants' operation. Estimates of average mine tailings production worldwide range from 5 to 7 billion tons per year [3]. Mine tailings may contain metals, such as copper, nickel, and zinc, in relatively high concentrations (from $0.5 \%$ to $3 \%$ ), and occasionally precious metals, such as gold and silver [4]. For instance, the current flotation tailings produced at the Ural concentrators are characterized by copper and zinc content of $0.25-0.58 \mathrm{wt} . \%$ and $0.53-1.36 \mathrm{wt} . \%$, respectively [5].

The accumulation of such waste in tailing dumps can cause environmental impacts on local ecosystems. Oxidation and dissolution of sulfide minerals (mainly pyrite, chalcopyrite, and sphalerite) by acidophilic chemolithotrophic microorganisms [6] result in the contamination of surface waters 
and groundwater. This leads to acidic outflows characterized by elevated concentrations of sulfate, iron, and toxic metals [7]. Pyritic wastes can be regarded as technogenic raw materials for the recovery of nonferrous and precious metals [8], and such an approach may offer environmental benefits. The development of efficient technologies for processing sulfide ores' tailings will make it possible to obtain additional commercial products and reduce the negative impact on the environment at waste storage sites [9].

High contents of nonferrous metals characterize slags from nonferrous metallurgy. On average, the production of 1 ton of copper results in the generation of 2.2-3 tons of slag [10]. The annual production of metallurgical slag is estimated at 400 million tons worldwide [11]. Approximately 110 million tons of slags from nonferrous metallurgy, with average copper and zinc contents of 1.4 and 3.5\% (wt.), respectively, had accumulated in the Urals as of 2013 [12]. Slags can be considered as technogenic raw materials for the production of nonferrous metals [11]. From an environmental point of view, metallurgical slags are hazardous materials due to heavy metals' dissolution during storage [13].

There is a growing scientific interest in biohydrometallurgical methods for the processing of sulfide raw materials [14]. In comparison with pyrometallurgical methods, biohydrometallurgical methods are considered eco-friendly approaches that reduce the negative impact of the mining and metallurgical industry on the environment [15]. However, bioleaching/bio-oxidation processes are characterized by a relatively low rate of sulfide mineral destruction and the toxicity of metals leached for microorganisms.

Sulfates of nonferrous metals and iron in the old pyritic flotation tailings dissolve readily in a sulfuric acid solution. Hence, a process based on the combination of the acid leaching and bioleaching steps can be appropriate for treating such waste. Acid leaching is used to extract nonferrous metals from the sulfates, while bioleaching is applied to leach the main amounts of copper and zinc from sulfides and oxidize pyrite. Pyrite is one of the most difficult sulfide minerals to oxidize in ferric sulfate solutions [16]. However, pyrite destruction is required for the efficient extraction of gold by cyanidation. Bioleaching of pyrite is based on the reactions summarized by the following equations [17]:

$$
\begin{gathered}
\mathrm{FeS}_{2}+14 \mathrm{Fe}^{3+}+8 \mathrm{H}_{2} \mathrm{O} \rightarrow 15 \mathrm{Fe}^{2+}+16 \mathrm{H}^{+}+2 \mathrm{SO}_{4}{ }^{2-}, \\
\mathrm{FeS}_{2}+2 \mathrm{Fe}^{3+} \rightarrow 3 \mathrm{Fe}^{2+}+2 \mathrm{~S}^{0}, \\
4 \mathrm{Fe}^{2+}+4 \mathrm{H}^{+}+\mathrm{O}_{2} \rightarrow 4 \mathrm{Fe}^{3+}+2 \mathrm{H}_{2} \mathrm{O}, \\
2 \mathrm{~S}^{0}+3 \mathrm{O}_{2}+2 \mathrm{H}_{2} \mathrm{O} \rightarrow 2 \mathrm{H}_{2} \mathrm{SO}_{4} .
\end{gathered}
$$

Recent studies have shown that the bioleaching of old pyritic tailings in bioreactors results in a high recovery of metals into the solution. However, due to the low content of nonferrous metals in such wastes, their leach solution concentrations were low, leading to difficulties in extracting them as products [18]. The leach solution contained mainly ferric sulfate.

Many papers have shown that slag from nickel and copper smelters contains more than $98 \%$ iron and cobalt and only 54-95\% nickel and copper as oxides, depending on the processing and furnace types [19]. Thus, common atmospheric acid leaching does not usually provide good yields for the extraction of copper and nickel $[20,21]$, explaining the need for oxidizing agents to leach metallurgical slags efficiently.

The chemical mechanism of metallurgical slag leaching using the ferric solution can be summarized by the following simplified reactions:

$$
\begin{gathered}
\mathrm{Cu}^{0}+2 \mathrm{Fe}^{3+} \rightarrow \mathrm{Cu}^{2+}+2 \mathrm{Fe}^{2+}, \\
\mathrm{MeS}+2 \mathrm{Fe}^{3+} \rightarrow \mathrm{Me}^{2+}+2 \mathrm{Fe}^{2+}+\mathrm{S}^{0} \\
\mathrm{Me}_{2} \mathrm{SiO}_{4}+2 \mathrm{H}_{2} \mathrm{SO}_{4} \rightarrow 2 \mathrm{MeSO}_{4}+\mathrm{H}_{4} \mathrm{SiO}_{4},
\end{gathered}
$$


where Me represents a metal $(\mathrm{Fe}, \mathrm{Zn}, \mathrm{Ni}, \mathrm{Cu})$.

Direct bioleaching of slag in the presence of elemental sulfur and/or ferrous sulfate resulted in approximately $70-80 \%$ and $4-14 \%$ recovery of copper and zinc, respectively. However, the duration of this process was 25 days [22].

Indirect leaching of copper converter slag flotation tailings with a biogenic ferric iron lixiviant generated using a moderately thermophilic acidophilic chemolithotrophic consortium resulted in the solubilization of $82 \%$ of copper within $1.5 \mathrm{~h}$ [21]. Previous studies on leaching metals from copper and copper-nickel slag by a solution obtained by the bio-oxidation of a commercial ferrous iron reagent determined the principal possibility and choice of optimal process parameters (temperature, $\mathrm{pH}$, and duration) $[23,24]$.

A previously proposed hydrometallurgical processing method involves treating copper converter slag flotation tailings with a leaching solution generated after sulfuric acid treatment of old pyritic flotation tailings containing ferric sulfate [25]. Although this process has been shown to be technically feasible, its industrial application is constrained by the relatively small amount of leach solution obtained. Thus, old pyritic tailings seem to be a promising source of ferric iron via leaching, especially considering their oxidation also allows the recovery of gold [18].

A new method based on using the solution generated after the bioleaching of industrial old pyritic flotation tailings for metallurgical slag leaching to increase the concentration of nonferrous metals in the pregnant leach solution is proposed in the current study. Investigation of the chemical and mineralogical composition of these wastes was carried out to justify the proposed method.

This study aimed to develop a complex biohydrometallurgical technology for the joint processing of mining and metallurgical wastes containing gold and other nonferrous metals. The economic benefits of this technology were also the subject for evaluation.

\section{Materials and Methods}

\subsection{Materials}

Wastes from mining and metallurgical processes, produced at plants in Russia, were the objects of research. These were (i) old flotation tailings of copper-zinc sulfide ores of the Urals (Russia), (ii) current converter slag obtained during the processing of copper sulfidic concentrates (Urals, Russia), and (iii) old slag of pyrometallurgical processing of copper-nickel sulfidic concentrates (Norilsk, Russia).

The chemical composition of the wastes used is shown in Table 1 . The old pyritic tailings contained small amounts of base metals but relatively large amounts $(0.67 \mathrm{~g} / \mathrm{t})$ of gold. This high gold content makes them a relatively valuable raw material. The content of base metals in the metallurgical slags was also relatively high.

Table 1. Content of elements in different types of wastes processed in this study.

\begin{tabular}{cccc}
\hline Element & Pyritic Tailings & Copper Slags & Copper-Nickel Slags \\
\hline $\mathrm{Fe}(\%)$ & 17.4 & 42.7 & 16.7 \\
$\mathrm{~S}(\%)$ & 17.8 & 5.0 & 1.88 \\
$\mathrm{Cu}(\%)$ & 0.26 & 2.74 & 2.12 \\
$\mathrm{Zn}(\%)$ & 0.22 & 2.49 & 0.024 \\
$\mathrm{Ni}(\%)$ & n.a. $^{\mathrm{a}}$ & 0.0061 & 2.66 \\
$\mathrm{Co}(\%)$ & n.a. & 0.0180 & 0.11 \\
$\mathrm{Si}(\%)$ & 9.3 & 9.4 & 17.1 \\
$\mathrm{Al}(\%)$ & 3.48 & 4.1 & 7.1 \\
$\mathrm{Ca}(\%)$ & 1.51 & n.a. & 4.01 \\
$\mathrm{Mg}(\%)$ & n.a. & n.a. & 2.34 \\
$\mathrm{Au}(\mathrm{g} / \mathrm{t})$ & 0.67 & 0.33 & $<0.1$ \\
\hline
\end{tabular}

a n.a.-not analyzed. 
Pyrite $\left(\mathrm{FeS}_{2}\right)$ was the main sulfide mineral (26\%) in the pyritic tailings. Copper and zinc were found as sulfides (chalcopyrite $\left(\mathrm{CuFeS}_{2}\right)$, bornite $\left(\mathrm{Cu}_{5} \mathrm{FeS}_{4}\right)$, and sphalerite $(\mathrm{ZnS})$ ) and oxidized compounds (sulfates) within the samples. Intergrowths with each other characterize sulfide minerals. The major gangue minerals were quartz $\left(\mathrm{SiO}_{2}\right)$ and gypsum $\left(\mathrm{CaSO}_{4} \cdot 2 \mathrm{H}_{2} \mathrm{O}\right)$. The content of jarosite $\left(\mathrm{NH}_{4}\left[\mathrm{Fe}_{3}\left(\mathrm{SO}_{4}\right)_{2}(\mathrm{OH})_{6}\right]\right)$ was found to be $1 \%$. The particle size distribution of the pyritic tailings had a $\mathrm{P}_{90}$ of $44 \mu \mathrm{m}$.

XRD patterns of metallurgical slags used in this work are shown in Figure 1. Fayalite $\left(\mathrm{Fe}_{2} \mathrm{SiO}_{4}\right)$, magnetite $\left(\mathrm{Fe}_{3} \mathrm{O}_{4}\right)$, and silicate glass were the main components of the slags. Optical microscope images of the copper and copper-nickel slags are shown in Figures 2 and 3, respectively. In both types of slag, copper was in the metallic form, as well as in the chalcocite $\left(\mathrm{Cu}_{2} \mathrm{~S}\right)$, bornite, covellite $(\mathrm{CuS})$, and chalcopyrite. Zinc was mainly dispersed in glassy silicates and fayalite in copper slag, while pyrite was also observed in copper slag. Nickel was found as serpentine $\left((\mathrm{Mg}, \mathrm{Fe}, \mathrm{Ni})_{3} \mathrm{Si}_{2} \mathrm{O}_{5}(\mathrm{OH})_{4}\right)$ in the copper-nickel slag. The particle size distribution of the wastes had a $\mathrm{P}_{95}$ of $71 \mu \mathrm{m}$.
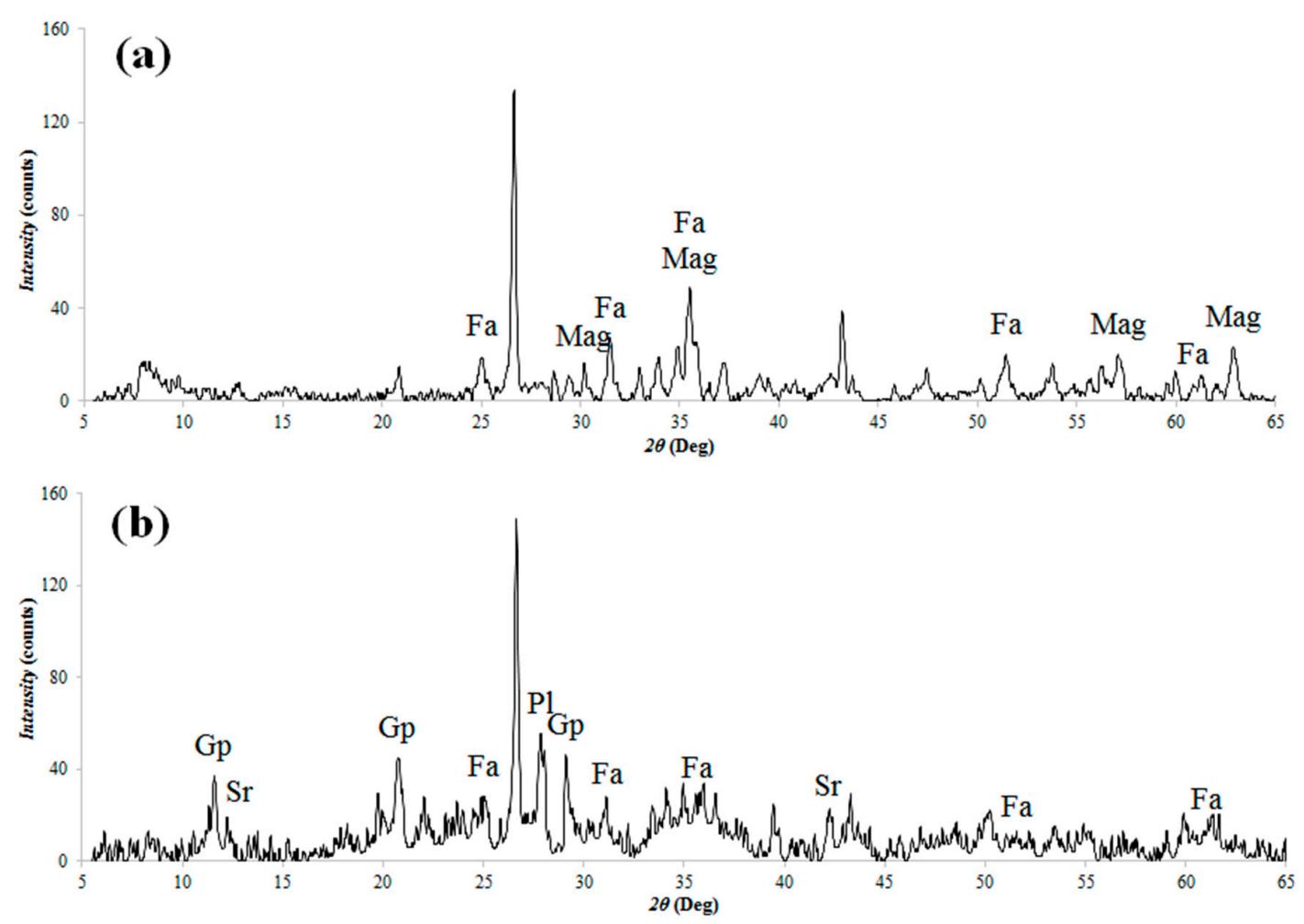

Figure 1. XRD patterns for the (a) copper slag and (b) copper-nickel slag (Gp, gypsum; Fa, fayalite; Mag, magnetite; Sr, serpentine; Pl, plagioclase).
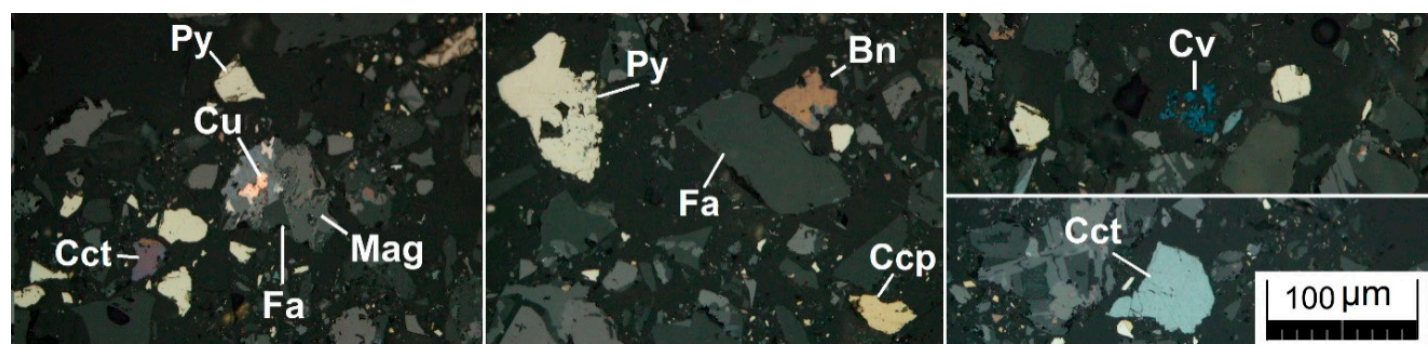

Figure 2. Optical micrographs of copper slag (Py, pyrite; $\mathrm{Cu}$, metallic copper; Ccp, chalcopyrite; Cct, chalcocite; Bn, bornite; $\mathrm{Cv}$, covellite; Fa, fayalite; Mag, magnetite). 

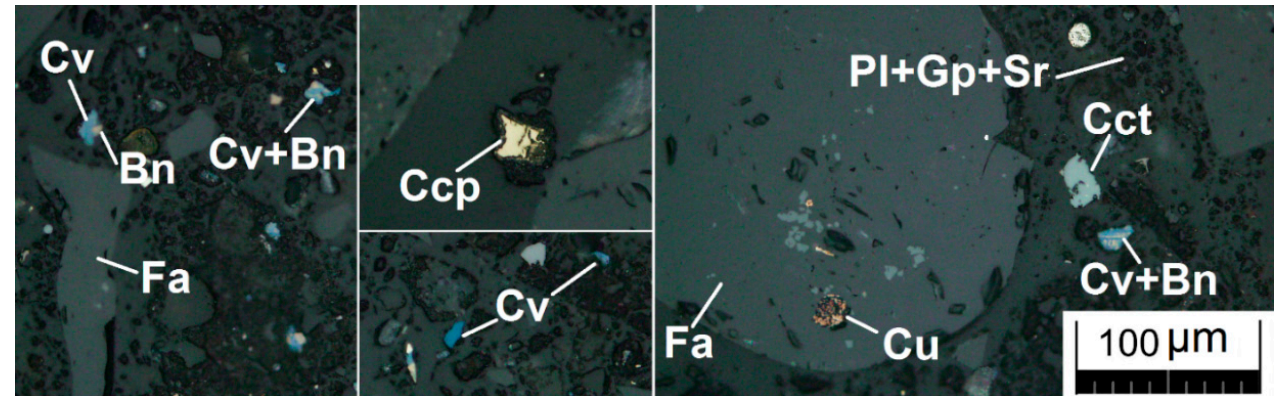

Figure 3. Optical micrographs of the copper-nickel slag $(\mathrm{Cu}$, metallic copper; $\mathrm{Ccp}$, chalcopyrite; Cct, chalcocite; Bn, bornite; $\mathrm{Cv}$, covellite; Fa, fayalite; $\mathrm{Pl}$, plagioclase; $\mathrm{Gp}$, gypsum; Sr, serpentine).

\subsection{Workflow of Waste Processing}

Even though only small amounts of sulfide minerals are present in most metallurgical slags, a complex biohydrometallurgical process based on indirect leaching could be promising [26,27]. It is well known that an increase in temperature accelerates chemical reactions, but organisms' vitality limits biological processes. Therefore, the use of a higher temperature in the abiotic step of slag leaching is justified.

The proposed processing of old pyritic tailings and metallurgical slags is shown in flow chart form in Figure 4. The process includes (i) the treatment of old pyritic tailings by a weak solution of sulfuric acid to remove readily soluble compounds of base metals; (ii) bioleaching of acid-treated pyritic tailings to leach base metals and liberate gold, producing a leach solution with a high ferric iron concentration; (iii) high-temperature leaching of metallurgical slag by the leach solution obtained during bioleaching of pyritic tailings.

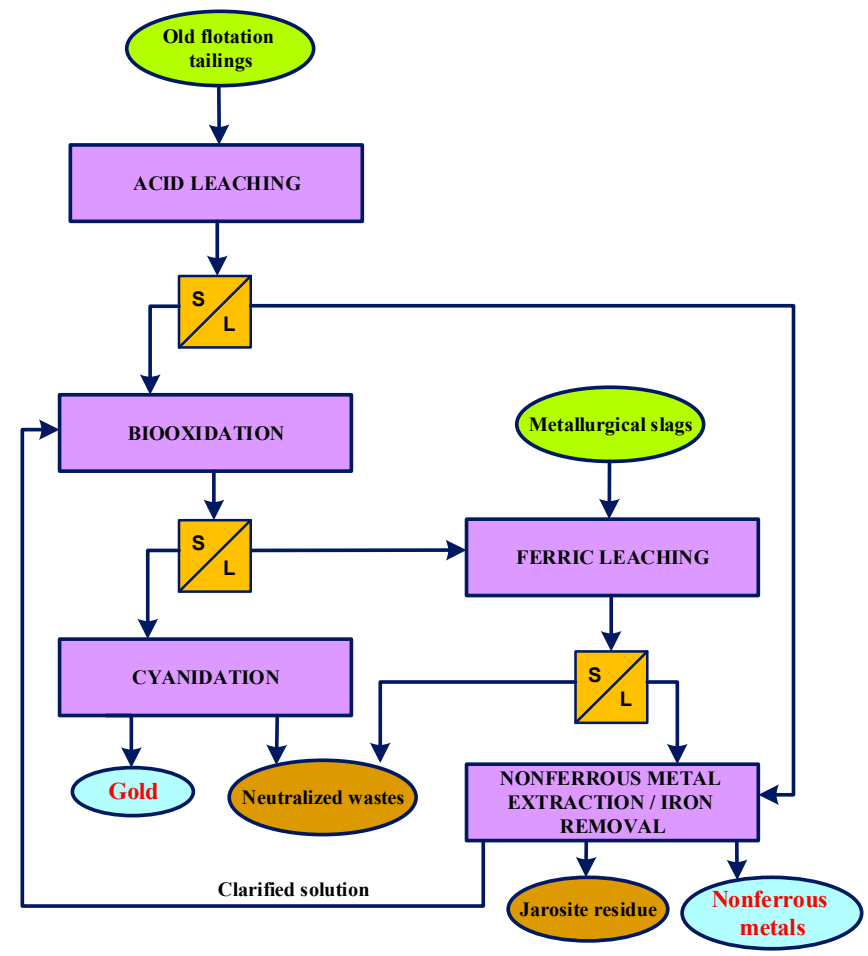

Figure 4. The flowsheet of processing of pyritic flotation tailings and metallurgical slag.

\subsection{Pyritic Waste Processing}

Leaching of the pyritic tailings by a sulfuric acid solution was conducted in a 2.0-L reactor with a working volume of $1.0 \mathrm{~L}$ and a stirring rate of $650 \mathrm{rpm}$ under batch conditions. The high stirring 
rate (as well as in the bioleaching and ferric leaching steps) was needed to maintain a homogeneous suspension and increase the rate of mass transfer. The pyritic tailings were leached using a previously reported efficient mode of acid treatment [9]: treatment at $20{ }^{\circ} \mathrm{C}, 40 \%(w / v)$ pulp density, $0.25 \%(w / w)$ sulfuric acid for $10 \mathrm{~min}$. The operation at the high pulp density (as well as at the bioleaching step) was used since it allows decreasing the tank volume at an industrial scale.

Bioleaching of the acid-treated pyritic tailings was conducted in two 2.0-L bioreactors with a working volume of $1.0 \mathrm{~L}$ that were connected in series. It has been stated that even in continuous stirred tank reactor operations, the limitation of pulp density is approximately $20 \%$ due to inefficient gas transfer in the system together with microbial cell damage due to the high shear force caused by the impeller [28]. Thus, the maximal pulp density selected for the bio-oxidation was $20 \%(w / v)$. The experiments were conducted with aeration at $4 \mathrm{~L} / \mathrm{min}$ and a stirring speed of an overhead 8-blade Rushton turbine impeller of $520 \mathrm{rpm}$. An iron-free 9K medium [29] was used as the aqueous phase. Enrichment culture isolated on the same medium from the pyritic tailings $(5 \%(w / v))$ at $35^{\circ} \mathrm{C}$ in shaking flasks with a working volume of $100 \mathrm{~mL}$ was used as inoculum. Enrichment culture of microorganisms contained Leptospirillum spp., Sulfobacillus spp., Ferroplasma spp., and Acidithiobacillus spp. At. caldus has been previously shown to predominate and play a key role in microbial communities during the bioleaching of pyrite raw materials due to the high rate of sulfur compounds oxidation [30,31]. Thus, a culture of the sulfur-oxidizing At. caldus strain INMI-10, which contained approximately $1 \times 10^{9}$ cells $/ \mathrm{mL}$, was also added $(10 \%(v / v))$ to the enrichment culture. The enrichment culture structure was studied by metabarcoding analysis with specific molecular markers (V3-V4 hypervariable region of the 16S rRNA gene) [32]. Bioreactors were kept under semi-continuous conditions with periodized manual effluent removal and feeding ( $16.7 \%$ of the pulp in each bioreactor once per day). This procedure was repeated for 21 cycles to reach a steady state. Prior to the beginning of the semi-continuous procedure, inoculum $(100 \mathrm{~mL}, 10 \%(v / v))$ containing approximately $1 \times 10^{9}$ cells $/ \mathrm{mL}$ was added to each bioreactor containing $900 \mathrm{~mL}$ of the medium and $200 \mathrm{~g}$ of the solid sample to carry out a two-week pre-cultivation. Additions of calcium oxide were made to maintain the $\mathrm{pH}$ in the primary bioreactor 1.4 to 1.5 , and 1.2 to 1.3 in the secondary one. Distilled water was added to the bioreactors using peristaltic pumps to compensate for evaporation losses. The pulp from the secondary bioreactor was centrifuged at $2000 \mathrm{rpm}$ for $5 \mathrm{~min}$. The aqueous phase was diluted with a sulfuric acid solution ( $\mathrm{pH}$ 1.3) to decrease the ferric iron concentration from 26.6 to $15.0 \mathrm{~g} / \mathrm{L}$, and this resultant solution was used as a lixiviant for ferric leaching of the slags.

\subsection{Leaching of Metals from Slags}

Ferric leaching was carried out in a $1.0-\mathrm{L}$ reactor at $70{ }^{\circ} \mathrm{C}, \mathrm{pH} 1.3-1.5$, with a pulp density of $10 \%(w / v)$ and a stirring rate of $760 \mathrm{rpm}$. The temperature was maintained using heat exchangers connected to a thermostat. Leaching was carried out under batch conditions. The solid phase was loaded and mixed with the $\mathrm{Fe}^{3+}$-containing solution obtained after bioleaching the pyritic tailings or after bio-oxidation of a ferrous sulfate reagent (control tests). The enrichment culture obtained with the pyritic tailings was used as an inoculum to obtain a ferric iron-containing culture liquid for the control tests. The bio-oxidation of ferrous iron $\left(\mathrm{FeSO}_{4} \cdot 7 \mathrm{H}_{2} \mathrm{O}\right)$ was conducted in a 5.0 - $\mathrm{L}$ vessel that contained $4.0 \mathrm{~L}$ of the liquid incubated at $35^{\circ} \mathrm{C}$ with an aeration rate of $4 \mathrm{~L} / \mathrm{min}$. The liquid phase consisted of the 9K medium and $10 \%(v / v)$ inoculum. The $\mathrm{Fe}^{3+}$ concentration was $15 \mathrm{~g} / \mathrm{L}(\mathrm{pH} 1.3)$. The cell density was found to be $6 \times 10^{8}$ cells/mL. The lixiviants were preheated to the desired temperature. Sulfuric acid $(98.5 \%)$ was added when necessary to maintain the desired $\mathrm{pH}$.

\subsection{Analytical Methods}

The values of the $\mathrm{pH}$ and Eh were measured with a $\mathrm{pH}-150 \mathrm{MI} \mathrm{pH}$ meter-millivoltmeter (Izmeritelnaya tekhnika, Russia). The $\mathrm{Fe}^{3+}$ and $\mathrm{Fe}^{2+}$ ions concentrations in the liquid phase were determined by reaction with potassium thiocyanate [33] using a PE-5400UF photometer (ECROSKHIM, St. Petersburg, Russia) at $\lambda=475 \mathrm{~nm}$. The total iron concentration was determined by the same method after the sample's 
reaction with ammonium persulfate. The ferrous ion concentration was defined as the difference between the values for ferric and total iron. The concentrations of copper, zinc, nickel, and cobalt ions in solutions were determined using atomic absorption spectroscopy (AAS) (Perkin Elmer 3100, PerkinElmer, Waltham, MA, USA).

Solids were analyzed by a wet chemical method, using 1:3 concentrated nitric acid: concentrated hydrochloric acid at the boiling temperature of the mixture, followed by AAS (Perkin Elmer AAnalyst-800, PerkinElmer, Waltham, MA, USA) for metal analysis and gravimetric analysis with barium chloride for sulfur [34]. The wastes' mineralogical composition was determined using X-ray diffraction with a DRON-2 diffractometer (Burevestnik, St. Petersburg, Russia) and/or polarizing microscopy with an Olympus BX51 microscope (Olympus, Tokyo, Japan). The sulfidic mineral contents were calculated considering the element contents determined using wet chemical methods.

The gold content in the solid phase was measured using a fire assay [35]. The extent of gold recovery was determined by carbon-in-pulp cyanidation using a pulp density of 33\% (w/v), $\mathrm{pH} 10-11$ (adjusted using aq. sodium hydroxide), a sodium cyanide concentration of $1.0 \mathrm{~g} / \mathrm{L}$, aeration of $25 \mathrm{~L} / \mathrm{h}$, and a sorbent content (carbon Norit 3515) of $8 \%(w / v)$ at $20{ }^{\circ} \mathrm{C}$. The experiments were run under batch conditions in a stirred-tank reactor with a working volume of $1.0 \mathrm{~L}$ at a stir speed of $200 \mathrm{rpm} \mathrm{for} 24 \mathrm{~h}$. The adsorption level of the gold on the sorbent was 99-100\%.

Residue yield (wt.\%) was calculated from the following equation:

$$
\gamma=\frac{m_{r}}{m_{\text {in }}} \cdot 100 \%
$$

where $m_{r}$ - the weight of leach residue $(\mathrm{g}) ; m_{\text {in }}$-the weight of the original sample in pulp $(\mathrm{g})$.

Metal recoveries from the pyritic tailings were calculated from the following equation:

$$
\varepsilon=100-\frac{\beta_{i \cdot \gamma}}{\beta_{i n}}
$$

where $\varepsilon$ is the metal recovery (wt.\%); $\gamma$ is the residue yield (wt. $\%$ ); $\beta_{\text {in }}$ and $\beta_{i}$ is the metal content in solids before and after bioleaching (after cyanidation for gold), respectively (wt.\%).

Metal recoveries from the slags (wt.\%) were calculated from the following equation:

$$
\varphi=\frac{C \cdot V}{10 \cdot \beta_{\text {in }} \cdot m_{\text {in }}},
$$

where $C$ is the metal concentration in leach solution $(\mathrm{mg} / \mathrm{L}), V$-a solution volume (L).

The leaching experiments were conducted in triplicate and bioleaching experiments in duplicate to calculate the confidence interval.

\section{Results and Discussion}

\subsection{Processing Old Pyritic Flotation Tailings (1st Leaching Step)}

Table 2 shows the results of the extraction of nonferrous metals after acid leaching and bioleaching. The data indicate that $36 \%$ of copper and $35 \%$ of zinc were extracted from the tailings at the acid leaching step, with $1.2 \%$ of iron extracted. As previously shown, the acidic solution can be used repeatedly (at least four times) until the concentrations required for extraction of nonferrous metals (1.0-1.2 g/L) are reached [15]. Additional amounts of nonferrous metals (from bornite, chalcopyrite, and sphalerite) were released into the liquid phase at the bioleaching step. The acidophilic microbial consortium consisted of iron (Leptospirillum spp., Sulfobacillus spp., and Ferroplasma spp.) and sulfur oxidizers (Sulfobacillus spp. and Acidithiobacillus spp.), the role of which was an oxidant regeneration and sulfuric acid production in the pulp (non-contact leaching). Additionally, the iron oxidizers accelerate the oxidation of sulfide minerals due to a cell attachment to the mineral surface (contact leaching), while sulfur-oxidizers can remove sulfur-containing secondary compounds from the mineral surface [36-38]. After acid leaching 
and 12 days of bioleaching, the total extraction of metals from pyritic tailings into the liquid phase reached $68 \%$ for copper, $77 \%$ for zinc, and $75 \%$ for iron. Base (calcium oxide) was added as required to maintain the target $\mathrm{pH}$ value. The decrease in the $\mathrm{pH}$ was caused by pyrite oxidation as well as jarosite formation. The consumption of calcium oxide in the primary and secondary bioreactors was 15 and $11 \mathrm{~g}$ calcium oxide/ $\mathrm{kg}$ tailings, respectively. The total amount of microbial cells was found to be the same in both bioreactors and amounted to $(0.5-1.0) \times 10^{9}$ cells $/ \mathrm{mL}$.

Table 2. Results of processing of pyritic tailings.

\begin{tabular}{|c|c|c|c|c|c|c|}
\hline \multirow{2}{*}{ Step } & \multirow{2}{*}{ Retention Time } & \multirow{2}{*}{$\begin{array}{l}\text { Total Residue } \\
\text { Yield }(\%)\end{array}$} & \multicolumn{3}{|c|}{ Total Extraction (\%) } & \multirow{2}{*}{$\begin{array}{c}\text { Total Pyrite } \\
\text { Oxidation (\%) }\end{array}$} \\
\hline & & & $\mathrm{Cu}$ & $\mathrm{Zn}$ & $\mathrm{Fe}$ & \\
\hline Acid leaching & $10 \mathrm{~min}$ & $\begin{array}{l}100 \\
\text { Bioleach }\end{array}$ & $36 \pm 4$ & $35 \pm 6$ & $1.2 \pm 0.1$ & 0 \\
\hline $\begin{array}{l}\text { Primary bioreactor } \\
\text { Secondary bioreactor }\end{array}$ & $\begin{array}{l}6 \text { days } \\
6 \text { days }\end{array}$ & $\begin{array}{l}79 \pm 2 \\
69 \pm 3\end{array}$ & $\begin{array}{l}57 \pm 6 \\
68 \pm 10\end{array}$ & $\begin{array}{c}61 \pm 6 \\
77 \pm 11\end{array}$ & $\begin{array}{c}57 \pm 3 \\
75 \pm 14\end{array}$ & $\begin{array}{l}65 \pm 5 \\
90 \pm 8\end{array}$ \\
\hline
\end{tabular}

XRD patterns after bioleaching of pyritic tailings are given in Figure 5. The residues' XRD patterns indicate a decrease in pyrite peaks and the appearance of peaks of jarosite and bassanite relative to the original tailings. Jarosite is a secondary precipitate formed during the bioleaching of sulfide minerals:

$$
3 \mathrm{Fe}_{2}\left(\mathrm{SO}_{4}\right)_{3}+12 \mathrm{H}_{2} \mathrm{O}+\mathrm{M}_{2} \mathrm{SO}_{4} \rightarrow 2 \mathrm{M}\left[\mathrm{Fe}_{3}\left(\mathrm{SO}_{4}\right)_{2}(\mathrm{OH})_{6}\right] \downarrow+6 \mathrm{H}_{2} \mathrm{SO}_{4}
$$

where $\mathrm{M}=\mathrm{K}, \mathrm{NH}_{4}, \mathrm{H}_{3} \mathrm{O}$.
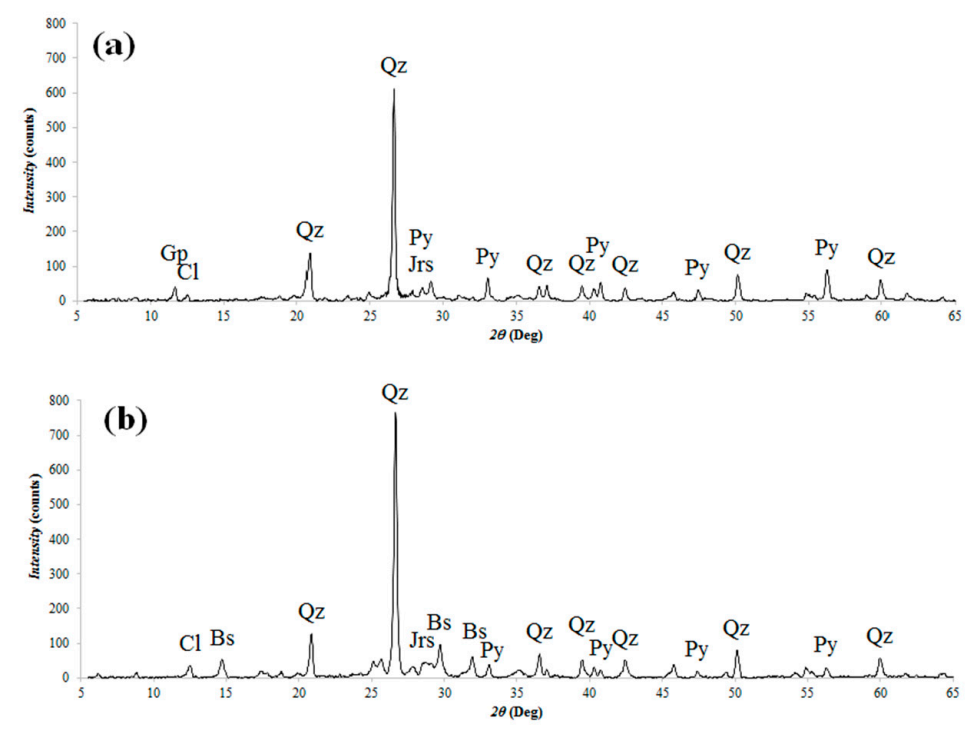

(c)

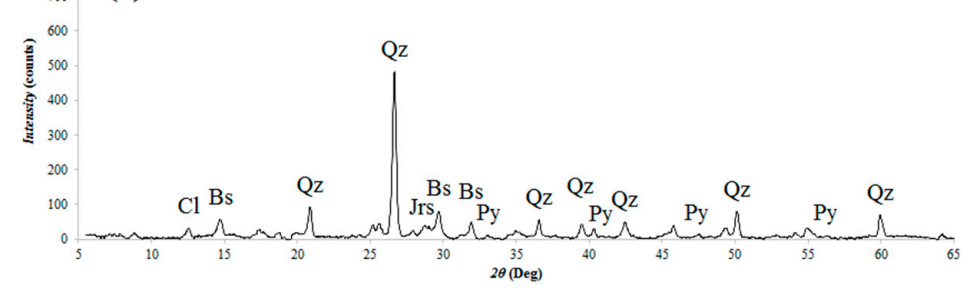

Figure 5. XRD patterns of the original pyritic tailings (a) and the residues after bioleaching of pyritic tailings in (b) primary and (c) secondary bioreactor (Py, pyrite; Qz, quartz; Gp, gypsum; Bs, bassanite; $\mathrm{Cl}$, chlorite; Jrs, jarosite). 
The content of jarosite in the residue from both bioreactors was 13\%. Jarosite is a common byproduct of the bio-oxidation of sulfides containing iron. During the bio-oxidation of pyrite/arsenopyrite gold-bearing concentrates, jarosite is known to be an abundant mineral phase of bioleaching residues [39-41]. For instance, a bioleaching residue in the BIOX ${ }^{\circledR}$ plant (Outotec, Espoo, Finland) at the Wiluna Mine contained approximately $25 \mathrm{wt}$.\% of jarosite [42]; a bio-oxidized product from another BIOX ${ }^{\circledR}$ plant in Ghana contained $3-4 \%$ of jarosite that was caused by low content of sulfidic sulfur ( $8.22 \mathrm{wt} . \%)$ in the flotation concentrate [43]. Jarosite was observed in the mesophile and thermophile BIOX ${ }^{\circledR}$ pilot plant products from Fairview Mine, with more jarosite present $(15 \mathrm{wt} . \%)$ in the products of the thermophile process [44]. The bioleaching of a concentrate containing $28 \%$ of pyrite in shaking flasks with a moderate thermophilic culture at a pulp density of $10 \%$ resulted in residue containing approximately $15 \mathrm{wt} . \%$ of jarosite [28]. The high content of jarosite (32 wt.\%) was observed during a continuous stirred tank bioleaching of a flotation concentrate of the tailings from Western Tasmania containing $70.5 \mathrm{wt} . \%$ of pyrite with a moderate thermophilic microbial culture [45]. It is known that the properties of bioleaching residue are dependent on the ionic composition and their concentration in the leachate (ferric iron, sulfates, and alkali ions), $\mathrm{pH}$ value, temperature, and the level of sulfide oxidation [46]. The jarosite content in the residue after bioleaching of pyritic tailings was relatively low due to moderate process temperatures, low content of sulfides in the tailings, and the controlled $\mathrm{pH}$ (less than 1.5). The pyrite oxidation rate in the primary bioreactor was $11 \mathrm{~g} \cdot \mathrm{g}^{-1} \cdot \mathrm{h}^{-1}$, and only $4 \mathrm{~g} \cdot \mathrm{g}^{-1} \cdot \mathrm{h}^{-1}$ in the secondary one (Table 2). The formation of jarosite on pyrite's surface during its bioleaching was among the probable reasons for the incomplete oxidation of pyrite. Asamoah et al. (2019) have found that bio-oxidation of a flotation concentrate produced jarosite that attenuated the oxidation process due to surface passivation and blocking of sulfide fissures [43,47]. Liu et al. [48] showed that removing jarosite from the residue after pyrite bioleaching increased the efficiency of subsequent pyrite oxidation. The bassanite (the product of the reaction between sulfuric acid and calcium oxide) content was $14 \%$ in the primary bioreactor and $17 \%$ in the secondary one.

Examination of the residues' representative optical micrographs (Figure 6) reveals single particles of sphalerite and the absence of bornite. The chalcopyrite content remained the same as in the original tailings after acid leaching and bioleaching due to chalcopyrite being generally recalcitrant to bioleaching at low and moderate temperatures and the mass losses of the solids during bioleaching. Thus, the slightly elevated copper extraction in the secondary bioreactor compared to the primary is associated with the surface of mineral particles' passivation by the reaction products [49].

Carbon-in-pulp cyanidation of bio-oxidized residues provided high gold recovery (Table 3) after 12 days of bioleaching due to the high pyrite oxidation level. Previous studies have shown that the efficiency of gold recovery is strongly related to the extent of sulfide oxidation and that the dependence of gold recovery on sulfide oxidation is often linear [28,39]. Although no effects of the jarosite amount, presence of secondary residues, etc., on gold recovery from pyritic materials were usually observed, in a few studies, gold particles coated by a jarosite layer were found [50]. Cyanide consumption was low in the case of the bio-oxidized residues compared to unleached tailings due to pyrite and soluble copper compounds inactivating the cyanide ion in the latter [51,52]. It is known that elemental sulfur, jarosite, sulfates, and sulfides can consume significant cyanide amounts due to the formation of thiocyanate and hexacyanoferrate $[39,43]$. The cyanide consumption in this study was found to be low compared to that obtained in many laboratory studies or industrial plants. At a laboratory scale, Ciftci and Akcil observed a cyanide consumption of approximately $7-17 \mathrm{~kg} / \mathrm{t}$ during the leaching of the bio-oxidized pyrite concentrates [28], while Mubarok et al. found this value to be 4-10 kg/t [53] depending on the bio-oxidation conditions. Jones and Hackl have found that gold leaching from bio-oxidized pyrite/arsenopyrite concentrates consumed 10-15 kg/t [54]. Cyanidation of BIOX ${ }^{\circledR}$ pilot plant products from Fairview Mine required $5 \mathrm{~g} / \mathrm{t}$ of sodium cyanide for mesophilic culture and $20 \mathrm{~g} / \mathrm{t}$ of sodium cyanide for thermophilic culture [44]. Leaching of the bio-oxidized pyrrhotite-containing pyrite/arsenopyrite concentrate resulted in a high cyanide consumption $(35 \mathrm{~kg} / \mathrm{t})$ due to high elemental 
sulfur concentration in the residue [55]. The absence of the organic carbon in the pyritic tailings had a preg-robbing effect, preventing the exceed cyanide consumption [56,57].
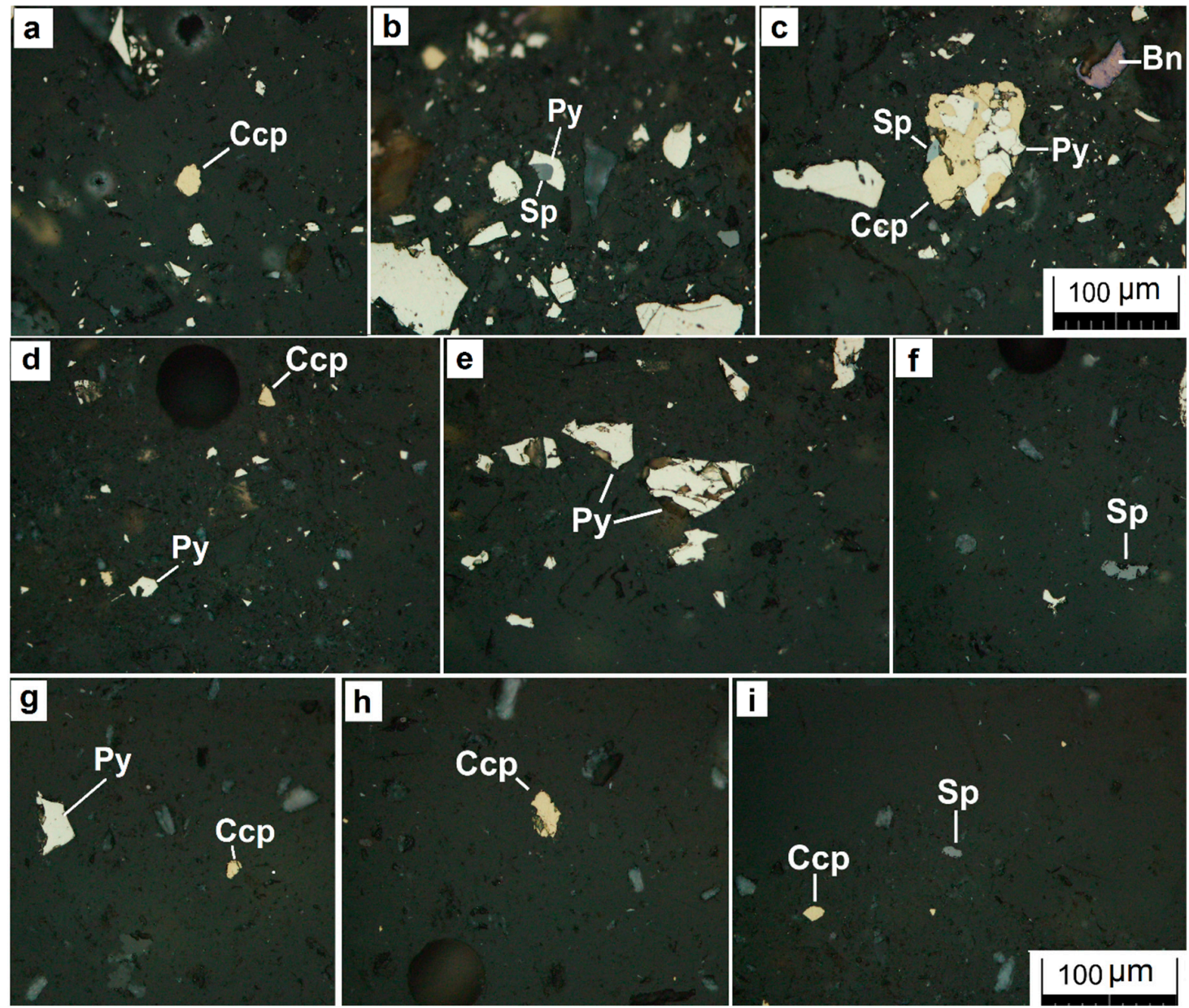

Figure 6. Optical micrographs of the pyritic tailings (a-c) and the residues after bioleaching in (d-f) primary and (g-i) secondary bioreactor (Py, pyrite; Ccp, chalcopyrite; Bn, bornite; Sp, sphalerite).

Table 3. The results of carbon-in-pulp cyanidation.

\begin{tabular}{cccc}
\hline Material & Bioreactor & Gold Recovery (\%) & NaCN Consumption (kg/t Tailings) \\
\hline Original tailings & - & $50 \pm 3$ & $10 \pm 2$ \\
Residue after bioleaching & Primary & $80 \pm 7$ & $3.3 \pm 0.5$ \\
& Secondary & $92 \pm 12$ & $2.8 \pm 0.1$ \\
\hline
\end{tabular}

Thus, the proposed biohydrometallurgical approach allows extraction of gold and other nonferrous metals from the wastes of sulfide ore concentration, as well as oxidation of pyrite, the main sulfide component in such wastes.

The leach solution generated by bioleaching pyritic tailings had the following characteristics: $26.6 \mathrm{~g} / \mathrm{L} \mathrm{Fe}^{3+}, 0.13 \mathrm{~g} / \mathrm{L} \mathrm{Cu}^{2+}, 0.23 \mathrm{~g} / \mathrm{L} \mathrm{Zn}^{2+}, \mathrm{pH} 1.3$, Eh $880 \mathrm{mV}$.

\subsection{Leaching Metal from Slag (2nd Leaching Step)}

The secondary bioreactor solution for bioleaching of pyritic tailings was diluted with a sulfuric acid solution in distilled water ( $\mathrm{pH} 1.3$ ) to a final ferric iron concentration of $15.0 \mathrm{~g} / \mathrm{L}$ and used for chemical leaching. The concentrations of copper and zinc in this solution were 0.073 and $0.13 \mathrm{~g} / \mathrm{L}$, respectively. The biosolution was used to increase the concentrations of leached nonferrous metals. 
Increased concentrations of nonferrous metals in the solution would enable more efficient final metal recovery.

Two different types of slags were used to test the possibility of processing wastes with different chemical compositions.

Ferric leaching of copper slags with the biosolution of ferric iron was carried out for $150 \mathrm{~min}$. Figure 7a shows the results of ferric leaching of copper smelter slags. According to these data, recovery levels of copper, zinc, and iron from copper slags were $88.9 \%, 43.4 \%$, and $21.7 \%$, respectively. This suggests that iron and zinc recovery levels from the wastes were low, while the copper recovery was substantially higher. This is caused by a more rapid reaction of the blister copper and copper sulfides with ferric iron than fayalite and zinc silicates with sulfuric acid.
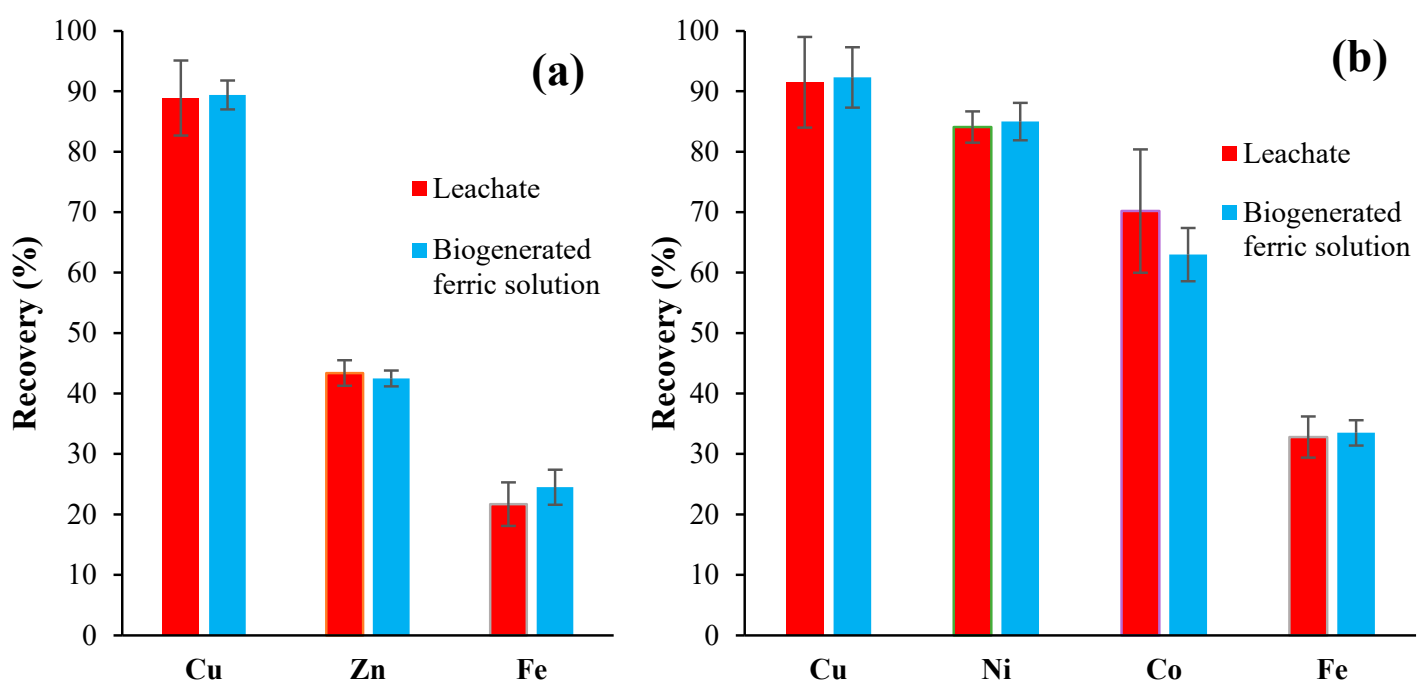

Figure 7. Metal extraction from (a) copper slag and (b) copper-nickel slag after leaching with the ferric iron-containing solutions.

Chemical leaching of the copper-nickel slags with the biosolution of ferric iron was carried out for $120 \mathrm{~min}$. Figure $7 \mathrm{~b}$ shows the results of leaching of the slag obtained during the processing of copper-nickel sulfide raw materials. Leaching with the biosolution resulted in the extraction of $91.5 \%$ of copper, $84.1 \%$ of nickel, $70.2 \%$ of cobalt, and $32.8 \%$ of iron into the liquid phase. For both types of slags, the levels of metal extraction were found to be approximately the same both when using a biosolution after bioleaching of pyritic tailings and when using a biologically generated ferric iron-containing solution obtained by oxidizing the ferrous sulfate reagent, which indicated the absence of inhibitory components in the leachate.

Comparing these results with the results from leaching copper slags suggests that iron extraction was relatively low from both types, while the level of copper extraction was similar for all experiments. The results, which are characterized by low extraction of zinc and iron, are because these metals are in the form of silicates. The presence of ferric iron in the leaching solution inhibits silicate minerals' dissolution due to the formation and adsorption of iron precipitates on the particles of silicates [58]. Moreover, the acidity level maintained during the experiments ( $\mathrm{pH}$ 1.3-1.5) was relatively low and did not support silicates' efficient dissolution [59].

During the leaching of copper converter slag of pyrometallurgical processing of copper concentrates, copper and zinc concentrations increased to $2.51 \pm 0.09$ and $1.21 \pm 0.06 \mathrm{~g} / \mathrm{L}$, respectively. Leaching of copper-nickel slags of pyrometallurgical processing of copper-nickel concentrates resulted in an increase in the final concentrations of copper and zinc to $2.01 \pm 0.03$ and $0.143 \pm 0.006 \mathrm{~g} / \mathrm{L}$, respectively. The concentrations of nickel and cobalt were $2.34 \pm 0.08$ and $0.077 \pm 0.009 \mathrm{~g} / \mathrm{L}$, respectively. The copper and nickel concentrations in these leachates were sufficient for recovery. Concentrations of zinc and 
cobalt could be increased to high enough levels, enabling their recovery if the leachates were subjected to repeated leaching after metal extraction.

\subsection{Economic and Environmental Aspects}

Table 4 shows the value of the metals recovered from the pyritic tailings and the slags using the proposed process with the reported metal recovery rates.

Table 4. Values of metals are calculated based on the experimental data that can be produced from the different types of mining and metallurgical wastes during the sequential biohydrometallurgical processing.

\begin{tabular}{ccccccccccccc}
\hline \multirow{2}{*}{ Material } & \multicolumn{2}{c}{$\mathbf{C u}$} & \multicolumn{2}{c}{$\mathbf{Z n}$} & \multicolumn{2}{c}{$\mathbf{N i}$} & \multicolumn{2}{c}{ Co } & \multicolumn{2}{c}{ Au } & \multicolumn{2}{c}{ Total } \\
\cline { 2 - 12 } & $\mathbf{k g} / \mathbf{t}$ & $\mathbf{\$} / \mathbf{t}$ & $\mathbf{k g} / \mathbf{t}$ & $\mathbf{\$} / \mathbf{t}$ & $\mathbf{k g} / \mathbf{t}$ & $\mathbf{\$} / \mathbf{t}$ & $\mathbf{k g} / \mathbf{t}$ & $\mathbf{\$} / \mathbf{t}$ & $\mathbf{g} / \mathbf{t}$ & $\mathbf{\$} / \mathbf{t}$ & $\mathbf{\$} / \mathbf{t}$ \\
\hline Pyritic tailings & 1.77 & 10 & 1.69 & 3.4 & - & - & - & - & 0.573 & 3 & 16.4 \\
Copper slags & 24.4 & 140 & 10.8 & 22 & - & - & - & - & - & - & 162 \\
Copper-nickel slags & 19.4 & 110 & - & - & 22.4 & 280 & 0.77 & 25 & - & - & 415 \\
\hline
\end{tabular}

By considering the different pulp density during bioleaching of pyritic tailings and slags, as well as dilution of the leaching solution after bioleaching of pyritic tailings for slag processing, it can be calculated that the oxidation of 1 ton of pyritic tailings allows leaching of 1.2 tons of slag. Thus, the value of metals that can be obtained from joint processing of pyritic tailings and copper slag is $211 \$ /(1 \mathrm{t}$ of tailings $+1.2 \mathrm{t}$ of slag), and for pyritic tailings and copper-nickel slag, $514 \$ /(1 \mathrm{t}$ of tailings $+1.2 \mathrm{t}$ of slag). Despite this, a more detailed techno-economic analysis needs to be conducted to evaluate the proposed process's feasibility.

The environmental hazard of waste disposal after using this method would be lower than the storage of native wastes. The proposed biohydrometallurgical approach allows extraction of toxic metals from the wastes and the oxidation of pyrite. The low content of sulfide minerals in the leach residues will prevent the generation of acidic mine drainage containing toxic metals and sulfate ions, thereby reducing environmental risks. The jarosite residue forming during iron removal from the pregnant leach solution is another waste product in this method, and it can be considered dump waste that is relatively inert under aerobic conditions [60]. Nowadays, many studies are devoted to reusing jarosite residues as the component of construction materials or methods of its utilization [61,62].

\section{Conclusions}

The combined biohydrometallurgical processing of pyritic wastes and slags of nonferrous metallurgy is a promising method to recover metals from these technogenic raw materials. After acid leaching and 12 days of bioleaching, the total recovery of metals from pyritic tailings into the liquid phase was $68 \%$ for copper, $77 \%$ for zinc, and $75 \%$ for iron; gold recovery via cyanidation reached $92 \%$. The liquid phase obtained after the bioleaching of pyritic tailings (a biosolution of ferric iron) was used for chemical leaching of copper or copper-nickel slags. This allowed the dissolution of $88.9 \%$ of copper, $43.4 \%$ of zinc, and $21.7 \%$ of iron from copper slag. Ferric leaching of copper-nickel slag allowed recovery of $91.5 \%$ of copper, $84.1 \%$ of nickel, $70.2 \%$ of cobalt, and $32.8 \%$ of iron. The proposed method can decrease waste disposal's environmental hazard due to toxic metal removal and pyrite oxidation. Forming jarosite residue can be considered a waste product that is relatively stable under aerobic conditions.

Author Contributions: Conceptualization, N.F. and M.M.; methodology, N.F. and M.M.; validation, N.F. and M.M.; formal analysis, M.M.; investigation, N.F. and M.M.; data curation, M.M.; writing-original draft preparation, M.M. and N.F.; writing—review and editing, M.M.; visualization, M.M. All authors have read and agreed to the published version of the manuscript.

Funding: This research was funded by the Ministry of Science and Higher Education of the Russian Federation. 
Conflicts of Interest: The authors declare no conflict of interest. The funders had no role in the study's design; in the collection, analyses, or interpretation of data; in the writing of the manuscript, or in the decision to publish the results.

\section{References}

1. Wills, B.A.; Finch, J.A. Wills' Mineral Processing Technology: An Introduction to the Practical Aspects of Ore Treatment and Mineral Recovery, 8th ed.; Butterworth-Heinemann: Oxford, UK, 2015; p. 512.

2. Obe, R.; DeBrito, J.; Mangabhai, R.; Lye, C. Sustainable Construction Materials: Copper Slag. In Sustainable Construction Materials: Copper Slag; Woodhead Publishing: Cambridge, UK, 2017; pp. 1-322.

3. Edraki, M.; Baumgartl, T.; Manlapig, E.; Bradshaw, D.; Franks, D.; Moran, C. Designing mine tailings for better environmental, social and economic outcomes: A review of alternative approaches. J. Clean. Prod. 2014, 84, 411-420. [CrossRef]

4. Ceniceros-Gomez, A.; Macias-Macias, K.; de la Cruz-Moreno, J.; Gutierrez-Ruiz, M.; Martinez-Jardines, L. Characterization of mining tailings in Mexico for the possible recovery of strategic elements. J. S. Am. Earth Sci. 2018, 88, 72-79. [CrossRef]

5. Mustafin, S.K. Man-made gold-bearing mineral raw materials of the southern Urals: Nature, composition and prospects for use. Problemy Mineralogii, Petrografii i Metallogenii. Nauchnye Chteniya Pamyati P. N. Chirvinskogo. 2019, 22, 236-242.

6. Johnson, D.; Hallberg, K. The microbiology of acidic mine waters. Res. Microbiol. 2003, 154, $466-473$. [CrossRef]

7. Tripodi, E.; Rueda, J.; Cespedes, C.; Vega, J.; Gomez, C. Characterization and geostatistical modelling of contaminants and added value metals from an abandoned $\mathrm{Cu}-\mathrm{Au}$ tailing dam in Taltal (Chile). J. S. Am. Earth Sci. 2019, 93, 183-202. [CrossRef]

8. Kinnunen, P.; Kaksonen, A. Towards circular economy in mining: Opportunities and bottlenecks for tailings valorization. J. Clean. Prod. 2019, 228, 153-160. [CrossRef]

9. Muravyov, M.; Fomchenko, N. Biohydrometallurgical treatment of old flotation tailings of sulfide ores containing non-nonferrous metals and gold. Miner. Eng. 2018, 122, 267-276. [CrossRef]

10. Sarfo, P.; Das, A.; Wyss, G.; Young, C. Recovery of metal values from copper slag and reuse of residual secondary slag. Waste Manag. 2017, 70, 272-281. [CrossRef]

11. Piatak, N.; Parsons, M.; Seal, R. Characteristics and environmental aspects of slag: A review. Appl. Geochem. 2015, 57, 236-266. [CrossRef]

12. Sabanova, M.N.; Savin, A.G.; Shadrunova, I.; Orekhova, N. Typification of ural region copper slags; Practice and prospects of flotation processing at operating concentration plants. Tsvetnye Met. 2013, 8, 14-19.

13. Potysz, A.; van Hullebusch, E.; Kierczak, J.; Grybos, M.; Lens, P.; Guibaud, G. Copper Metallurgical Slags-Current Knowledge and Fate: A Review. Crit. Rev. Environ. Sci. Technol. 2015, 45, 2424-2488. [CrossRef]

14. Kaksonen, A.H.; Boxall, N.J.; Gumulya, Y.; Khaleque, H.N.; Morris, C.; Bohu, T.; Cheng, K.Y.; Usher, K.M.; Lakaniemi, A.M. Recent progress in biohydrometallurgy and microbial characterisation. Hydrometallurgy 2018, 180, 7-25. [CrossRef]

15. Fomchenko, N.; Muravyov, M. Two-step biohydrometallurgical technology of copper-zinc concentrate processing as an opportunity to reduce negative impacts on the environment. J. Environ. Manag. 2018, 226, 270-277. [CrossRef] [PubMed]

16. Riekkola-Vanhanen, M.; Heimala, S. Electrochemical control in the biological leaching of sulfide ores. In Proceedings of the International Biohydrometallurgy Symposium, Jackson Hole, WY, USA, 22-25 August 1993; pp. 561-570.

17. Sand, W.; Gehrke, T.; Jozsa, P.; Schippers, A. (Bio) chemistry of bacterial leaching—Direct vs. indirect bioleaching. Hydrometallurgy 2001, 59, 159-175. [CrossRef]

18. Muravyov, M. Bioprocessing of mine waste: Effects of process conditions. Chem. Pap. 2019, 73, 3075-3083. [CrossRef]

19. Li, Y.; Perederiy, I.; Papangelakis, V. Cleaning of waste smelter slags and recovery of valuable metals by pressure oxidative leaching. J. Hazard. Mater. 2008, 152, 607-615. [CrossRef] 
20. Perederiy, I.; Papangelakis, V. Why amorphous FeO-SiO2 slags do not acid-leach at high temperatures. J. Hazard. Mater. 2017, 321, 737-744. [CrossRef]

21. Muravyov, M.; Fomchenko, N.; Usoltsev, A.; Vasilyev, E.; Kondrat'eva, T. Leaching of copper and zinc from copper converter slag flotation tailings using $\mathrm{H}_{2} \mathrm{SO}_{4}$ and biologically generated $\mathrm{Fe}-2(\mathrm{SO} 4)(3)$. Hydrometallurgy 2012, 119, 40-46. [CrossRef]

22. Kaksonen, A.; Sarkijarvi, S.; Peuraniemi, E.; Junnikkala, S.; Puhakka, J.; Tuovinen, O. Metal biorecovery in acid solutions from a copper smelter slag. Hydrometallurgy 2017, 168, 135-140. [CrossRef]

23. Muravyov, M.I.; Fomchenko, N.V. Leaching of nonferrous metals from copper converter slag with application of acidophilic microorganisms. Appl. Biochem. Microbiol. 2013, 49, 562-569. [CrossRef]

24. Fomchenko, N.; Murav'ev, M. Obtaining of copper and nickel from metallurgical waste products with the use of acidophilic chemolithotrophic microorganisms. Appl. Biochem. Microbiol. 2015, 51, 388-392. [CrossRef]

25. Muravyov, M.I.; Bulaev, A.G.; Kondrat'eva, T.F. Complex treatment of mining and metallurgical wastes for recovery of base metals. Miner. Eng. 2014, 64, 63-66. [CrossRef]

26. Carranza, F.; Iglesias, N.; Mazuelos, A.; Romero, R.; Forcat, O. Ferric leaching of copper slag flotation tailings. Miner. Eng. 2009, 22, 107-110. [CrossRef]

27. Carranza, F.; Romero, R.; Mazuelos, A.; Iglesias, N.; Forcat, O. Biorecovery of copper from converter slags: Slags characterization and exploratory ferric leaching tests. Hydrometallurgy 2009, 97, 39-45. [CrossRef]

28. Ciftci, H.; Akcil, A. Effect of biooxidation conditions on cyanide consumption and gold recovery from a refractory gold concentrate. Hydrometallurgy 2010, 104, 142-149. [CrossRef]

29. Silverman, M.P.; Lundgren, D.G. Studies on the chemoautotrophic iron bacterium Ferrobacillus ferrooxidans. I. An improved medium and a harvesting procedure for securing high cell yields. J. Bacteriol. 1959, 77, 642-647. [CrossRef]

30. Gahan, C.; Sundkvist, J.; Sandstrom, A. A study on the toxic effects of chloride on the biooxidation efficiency of pyrite. J. Hazard. Mater. 2009, 172, 1273-1281. [CrossRef]

31. Bryan, C.; Joulian, C.; Spolaore, P.; El Achbouni, H.; Challan-Belval, S.; Morin, D.; d'Hugues, P. The efficiency of indigenous and designed consortia in bioleaching stirred tank reactors. Miner. Eng. 2011, 24, 1149-1156. [CrossRef]

32. Muravyov, M.; Panyushkina, A. Distinct Roles of Acidophiles in Complete Oxidation of High-Sulfur Ferric Leach Product of Zinc Sulfide Concentrate. Microorganisms 2020, 8, 386. [CrossRef]

33. Reznikov, A.A.; Mulikovskaya, E.P.; Sokolov, I.Y. Metody Analiza Prirodnykh Vod, 3rd ed.; Nedra: Moscow, Russia, 1970; p. 488.

34. Filippova, N.A. Phazovy Analiz Rud i Produktov Ikh Pererabotk, 2nd ed.; Khimiya: Moscow, Russia, $1975 ;$ p. 280.

35. Haffty, J.; Riley, L.B.; Goss, W.D. A Manual on Fire Assaying and Determination of the Noble Metals in Geological Materials; Geological Survey Bulletin 1445; U.S. Govt. Print. Off.: Washington, DC, USA, 1977; p. 58.

36. Vera, M.; Schippers, A.; Sand, W. Progress in bioleaching: Fundamentals and mechanisms of bacterial metal sulfide oxidation-part A. Appl. Microbiol. Biotechnol. 2013, 97, 7529-7541. [CrossRef]

37. Peng, T.; Chen, L.; Wang, J.; Miao, J.; Shen, L.; Yu, R.; Gu, G.; Qiu, G.; Zeng, W. Dissolution and Passivation of Chalcopyrite during Bioleaching by Acidithiobacillus ferrivorans at Low Temperature. Minerals 2019, 9, 332. [CrossRef]

38. Feng, S.; Yang, H.; Wang, W. Improved chalcopyrite bioleaching by Acidithiobacillus sp via direct step-wise regulation of microbial community structure. Bioresour. Technol. 2015, 192, 75-82. [CrossRef] [PubMed]

39. Lindstrom, E.; Gunneriusson, E.; Tuovinen, O. Bacterial oxidation of refractory sulfide ores for gold recovery. Crit. Rev. Biotechnol. 1992, 12, 133-155. [CrossRef]

40. Marquez, M.; Gaspar, J.; Bessler, K.; Magela, G. Process mineralogy of bacterial oxidized gold ore in Sao Bento Mine (Brasil). Hydrometallurgy 2006, 83, 114-123. [CrossRef]

41. Arroyave, D.; Gallego, D.; Marquez, M. Evaluation of residence time distribution and mineralogical characterization of the biooxidation of sulfide minerals in a continuous stirred tank reactor. Miner. Eng. 2013, 46-47, 128-135. [CrossRef]

42. Gagliardi, F.; Cashion, J. Mossbauer analysis of BIOX treatment of ores at Wiluna gold mine, Western Australia. Hyperfine Interact. 2013, 218, 95-99. [CrossRef]

43. Ofori-Sarpong, G.; Adam, A.-S.; Asamoah, R.K.; Amankwah, R.K. Characterisation of Biooxidation Feed and Products for Improved Understanding of Biooxidation and Gold Extraction Performance. Int. J. Miner. Process. Extr. Metall. 2020, 5, 20-29. [CrossRef] 
44. Kandengwa, M. Characterization of Jarosite Formed during Biooxidation of Refractory Gold Ores and Its Effect on Cyanide Consumption during Gold Leaching. Master's Thesis, University of Pretoria, Pretoria, South Africa, 2016.

45. Parbhakar-Fox, A.; Glen, J.; Raimondo, B. A Geometallurgical Approach to Tailings Management: An Example from the Savage River Fe-Ore Mine, Western Tasmania. Minerals 2018, 8, 454. [CrossRef]

46. Gramp, J.; Jones, F.; Bigham, J.; Tuovinen, O. Monovalent cation concentrations determine the types of Fe(III) hydroxysulfate precipitates formed in bioleach solutions. Hydrometallurgy 2008, 94, 29-33. [CrossRef]

47. Asamoah, R.K.; Zanin, M.; Gascooke, J.; Skinner, W.; Addai-Mensah, J. Refractory gold ores and concentrates part 1: Mineralogical and physico-chemical characteristics. Miner. Process. Extr. Metall. 2019, 1-13. [CrossRef]

48. Liu, F.; Shi, J.; Duan, J.; Zhou, L.; Xu, J.; Hao, X.; Fan, W. Significance of jarosite dissolution from the biooxidized pyrite surface on further biooxidation of pyrite. Hydrometallurgy 2018, 176, 33-41. [CrossRef]

49. Tanne, C.; Schippers, A. Electrochemical investigation of chalcopyrite (bio)leaching residues. Hydrometallurgy 2019, 187, 8-17. [CrossRef]

50. Asamoah, R.K.; Zanin, M.; Skinner, W.; Addai-Mensah, J. Refractory gold ores and concentrates part 2: Gold mineralisation and deportment in flotation concentrates and bio-oxidised products. Miner. Process. Extr. Metall. 2019, 1-14. [CrossRef]

51. Dai, X.; Simons, A.; Breuer, P. A review of copper cyanide recovery technologies for the cyanidation of copper containing gold ores. Miner. Eng. 2012, 25, 1-13. [CrossRef]

52. Medina, D.; Anderson, C. A Review of the Cyanidation Treatment of Copper-Gold Ores and Concentrates. Metals 2020, 10, 897. [CrossRef]

53. Mubarok, M.; Winarko, R.; Chaerun, S.; Rizki, I.; Ichlas, Z. Improving gold recovery from refractory gold ores through biooxidation using iron-sulfur-oxidizing/sulfur-oxidizing mixotrophic bacteria. Hydrometallurgy 2017, 168, 69-75. [CrossRef]

54. Jones, L.; Hackl, R.P. Sources of high cyanide consumption for a biooxidized refractory gold concentrate. In Process Metallurgy; Amils, R., Ballester, A., Eds.; Elsevier: Amsterdam, The Netherlands, 1999; Volume 9 , pp. 337-346.

55. Muravyov, M.; Fomchenko, N.; Kondrat'eva, T. Investigation of Steps of Ferric Leaching and Biooxidation at the Recovery of Gold from Sulfide Concentrate. Appl. Biochem. Microbiol. 2015, 51, 75-82. [CrossRef]

56. Edahbi, M.; Mermillod-Blondin, R.; Plante, B.; Benzaazoua, M. CIL Gold Loss Characterization within Oxidized Leach Tails: Creating a Synergistic Approach between Mineralogical Characterization, Diagnostic Leach Tests, and Preg-Robbing Tests. Minerals 2019, 9, 557. [CrossRef]

57. Chugaev, L.V.; Pleshkov, M.A.; Markelov, A.V. Studying the gold loss structure during cil of carbonaceous concentrate. Tsvetnye Met. 2020, 2020, 104-110. [CrossRef]

58. Santelli, C.; Welch, S.; Westrich, H.; Banfield, J. The effect of Fe-oxidizing bacteria on Fe-silicate mineral dissolution. Chem. Geol. 2001, 180, 99-115. [CrossRef]

59. Munoz, A.; Bevilaqua, D.; Garcia, O.; Donati, E.; Viera, M.; Tavani, E.; Giaveno, M.; Lavalle, T.; Chiacchiarini, P. Leaching of $\mathrm{Ni}$ and $\mathrm{Cu}$ from mine wastes (tailings and slags) using acid solutions and $\mathrm{A}$. ferrooxidans. In Biohydrometallurgy: A Meeting Point between Microbial Ecology, Metal Recovery Processes and Environmental Remediation; Trans Tech Publisher: Zurich, Switzerland, 2009; Volume 71-73, pp. 425-428. [CrossRef]

60. Islas, H.; Flores, M.; Reyes, I.; Juarez, J.; Reyes, M.; Teja, A.; Palacios, E.; Pandiyan, T.; Aguilar-Carrillo, J. Determination of the dissolution rate of hazardous jarosites in different conditions using the shrinking core kinetic model. J. Hazard. Mater. 2020, 386. [CrossRef] [PubMed]

61. Mombelli, D.; Mapelli, C.; Barella, S.; Gruttadauria, A.; Spada, E. Jarosite wastes reduction through blast furnace sludges for cast iron production. J. Environ. Chem. Eng. 2019, 7. [CrossRef]

62. Mymrin, V.; Ponte, H.; Impinnisi, P. Potential application of acid jarosite wastes as the main component of construction materials. Constr. Build. Mater. 2005, 19, 141-146. [CrossRef]

Publisher's Note: MDPI stays neutral with regard to jurisdictional claims in published maps and institutional affiliations. 